\title{
The River Settlement: Tree House as a solution safe from floods
}

\author{
Vera Nur Nabillah ${ }^{1}$, Azka Intasan $^{1}$, Esti Destikarani ${ }^{1}$ and M. Syaom Barliana ${ }^{1}$ \\ ${ }^{1}$ Universitas Pendidikan Indonesia, Architecture Program
}

\begin{abstract}
Flood is a natural disaster that occurs due to human behavior itself is less loving environment. One area that has been known to the public as flood-prone areas is Dayeuh Kolot located in the southern region of Bandung. Many factors that cause the occurrence of natural disasters flood. The purpose of this study is to obtain safe residential solutions from flood disasters that can be applied around the upper watershed of Citarum River. Data collection process is done by analyzing secondary data obtained from journals, online media, and related institutions.
\end{abstract}

\section{Introduction}

Dayeuh Kolot is a region in South Bandung that is known to the public as flood prone areas. It is proved by its location adjacent to the confluence of the Citarum River that is, the Cikapundung River and Citarum River itself [1]. Rainfall in South Bandung Region ranges from 3220-5409 $\mathrm{mm}$ with annual rainfall $4120 \mathrm{~mm}$ so that when it rains, river flow discharge can increase up to 578 $\mathrm{m} 3$ / dt which often causes flooding [2]. Maximum flood height that once hit the area of Dayeuh Kolot that is more than one meter and result in loss of property [3].

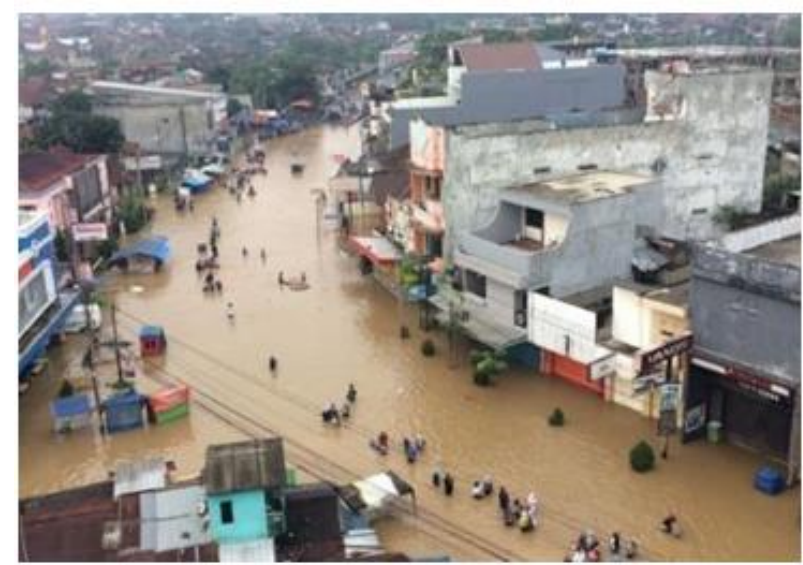

Fig. 1. Dayeuh Kolot condition in the event of a flood.

The cause of the Citarum River overflowed due to the increasing of residents thus increasing the need for shelter which leads to land conversion that is very intensive and not in accordance with the capacity and carrying capacity of the land [4]. The population in an area of Citarum River, especially in Bandung district increased from 2.848.077 in 2008 to 3.307.396 in 2010, and to 3.307 .396 in 2012 [5]. According to the Badan Pusat Statistik quoted in Kompas Daily, residents in the Citarum River area, especially Bandung district has now risen to 3.6 million which is increasingly affecting critical land in the upper watershed (Watershed) which often leads to flooding [6]. Settlements in the vicinity of the Citarum River flow also experienced a fairly high increase of approximately more $34.9 \%$ during the period 2001-2014 or from the residential area of 143,127 ha to 266,071 ha [7]. Garbage is also one of the factors causing Dayeuh floods. Lack of human awareness of the importance of environmental health has resulted in rivers becoming polluted by wastes of settlements, industry, agriculture, and farms [8]. The data shows as much as $60 \%$ is household waste, $30 \%$ of liquid chemical industry waste, and $10 \%$ of agricultural and farms waste. The volume of waste in Upper Citarum River area, which is around Bandung Regency has reached 500.000 $\mathrm{m} 3$ / year [9].

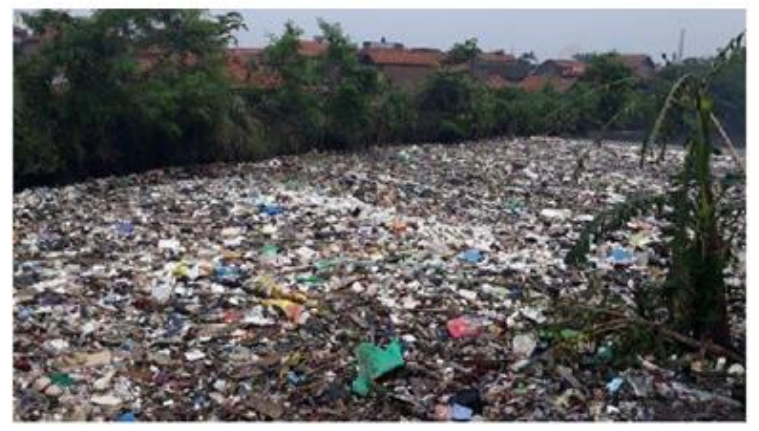

Fig. 2. Piles of garbage in the Citarum River Cangkuang Wetan Village, Dayeuh Kolot.

So, an experimental concept, Tree House, is expected to be able to parse the various problems. This idea aims to formulate effective solutions that in order to solve the problem of flooding in residential areas along the banks of the Citarum River.

\footnotetext{
* Corresponding author: veranur.nabillah@yahoo.com
} 


\section{Method}

The method used in this research is descriptivequalitative method by describing the state of the object of research where the object of this research is the watershed Citarum upstream in writing by revealing the situation, problems, based on facts at this time. In addition, this research also uses secondary data analysis methods that obtained from journals, online media, and related agencies.

\section{Results and discussions}

Tree House is a vertical dwelling as a solution of flood problems that occur in residential areas around the upper banks of the Citarum River. This building aims to create a safe haven for flood disasters accompanied by water and waste treatment systems so that it can be utilized by the surrounding community. This building can also solve the problem of settlement land that its availability is getting thinner.

\subsection{Form concept}

The building is analogous to a tree that has many benefits for human life on earth. In addition to being an $\mathrm{O} 2$ producer and provider of food reserves, trees are also a storage reserves for groundwater. The water absorption system by tree roots will be used as the main concept in this design.

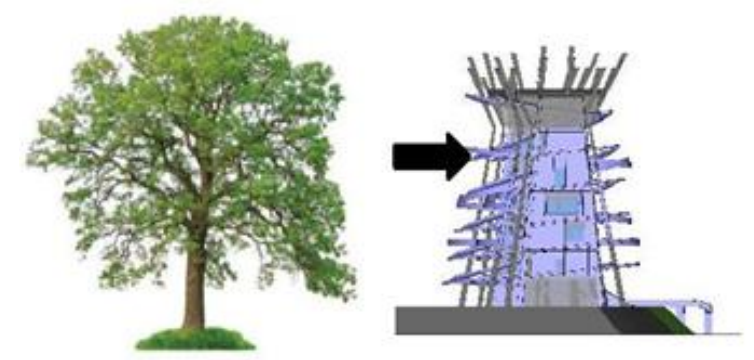

Fig. 3. The illustration of form concept.

\subsection{Zoning}

Tree House is divided into 4 main functions namely residential function, recreational function, water and waste treatment function, and garbage filtering function. The four functions are in a building mass that is integrated into each other to accommodate user activity inside. Zoning the four functions in the building can be seen in the illustration of the figure 4.

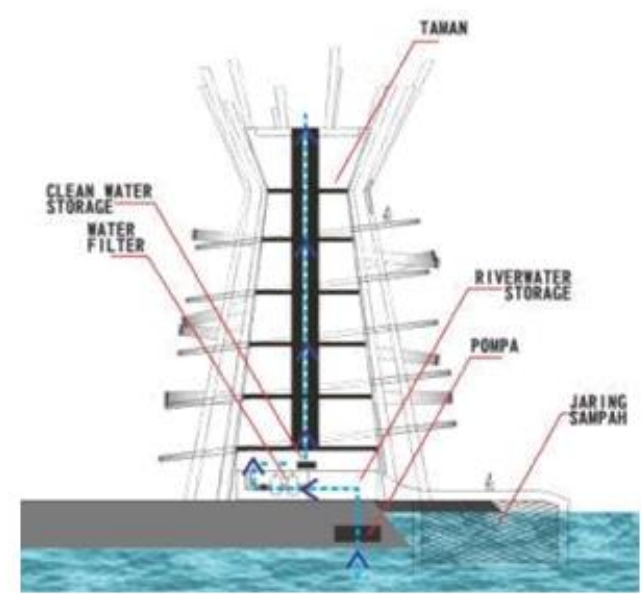

Fig. 4. The illustration of zoning concept.

a) Trash filter (-5.00)

- Net to take solid waste that flows in the river

- space to accommodate garbage (storage)

b) Water and waste treatment $(+0.00)$

- Water filtering - Water storage - Water pump

c) Residential (+4.00)

- Residential area (kitchen, km / wc, bedroom, living room, living room)

d) Residential (+8.00)

- Residential area (kitchen, $\mathrm{km} / \mathrm{wc}$, bedroom, living room, living room)

e) Residential $(+12.00)$

- Residential area (kitchen, $\mathrm{km} / \mathrm{wc}$, bedroom, living room, living room)

f) Residential (+16.00)

- Residential area (kitchen, km / wc, bedroom, living room, living room)

g) Residential $(+20.00)$

- Residential area (kitchen, $\mathrm{km} / \mathrm{wc}$, bedroom, living room, living room)

h) Communal space $(+24.00)$

- Garden

\subsection{The concept of circulation}

Circulation is used using radial circulation system by using a ramp width of 4 meters so it is enough to pass a two-way motorcycle. The radial circulation created around the residential units in the building looks like the illustration of the following picture. 


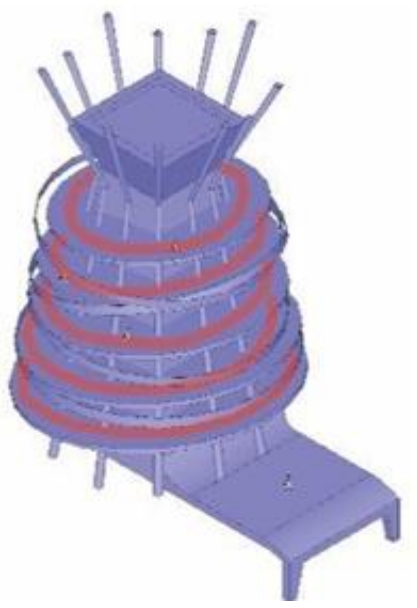

Fig. 5. Illustration of the concept of circulation.

\subsection{The concept of flood water treatment}

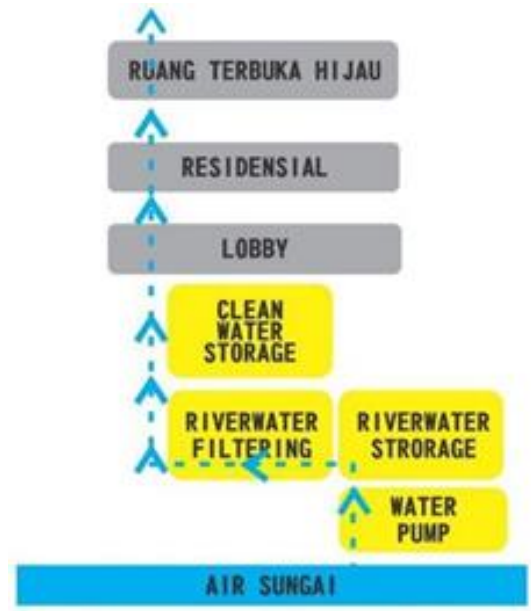

Fig. 6. Illustration of the concept of flood water treatment.

This water treatment system uses membrane technology. If the water overflows the water will be accommodated in the tub then filtered by sand filter (sand filter). Then in the process with membrane technology. The membrane technology used to treat this river water is the Ultra Filtration (UF) membrane. The pore size of the Ultra Filtration membrane is $0.01 \mu \mathrm{m}-0.001 \mu \mathrm{m}$, the dirty water passing through the Ultra Filtration (UF) membrane will be very clear. Protein, starch, antibiotics, colloidal silica, gelatine, organic, dyes, fat to bacteria can be filtered by Ultrafiltration (UF) membrane or Ultra Filtration, the water produced can be used for cooking, washing, bathing and so on. Then water can be consumed / drunk desalination process needs to reduce the salt level is by using Reverse Osmosis. Membrane which pores are very small $0.0001 \mu \mathrm{m}$. With its very small pore Reverse Osmosis Membrane is capable to filter metal ions, acids, sugars, salt liquid, dyes, natural resins, residual paints, monovalent, BOD, COD. So that the water produced at the end of this water treatment process is water that is feasible and safe to be consumed. After the process of filtering clean water will be in the container then in the pump and distributed to every dwelling.

\subsection{The concept of trash filtering}

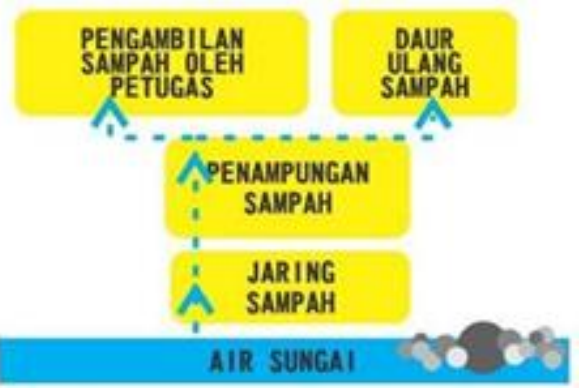

Fig. 7. Illustration of the concept of trash filtering.

Trash filtering system using fish pond system. Fish pond is a system that uses a net to catch its catch. In this case fish ponds switch from collecting fish to collecting trash. Every house on the riverbank will catch the trash from the river stream underneath it and then take it to the mainland and collect it to the landfill.

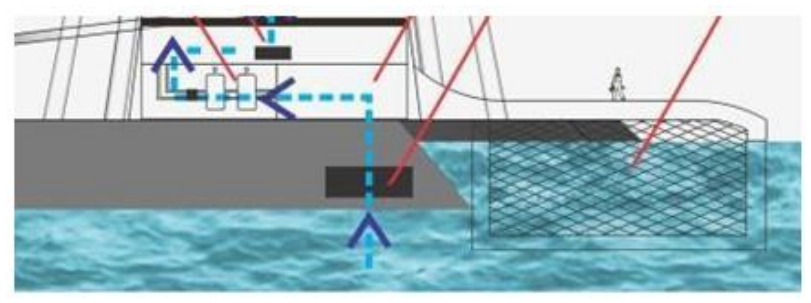

Fig. 8. Trash net.

\subsection{Structure concepts}

The road construction uses a steel pole (a substitute for a concrete pile in general) as a road holder. This is a new technology as it will be used in the construction of the Jakarta-Cikampek toll road.

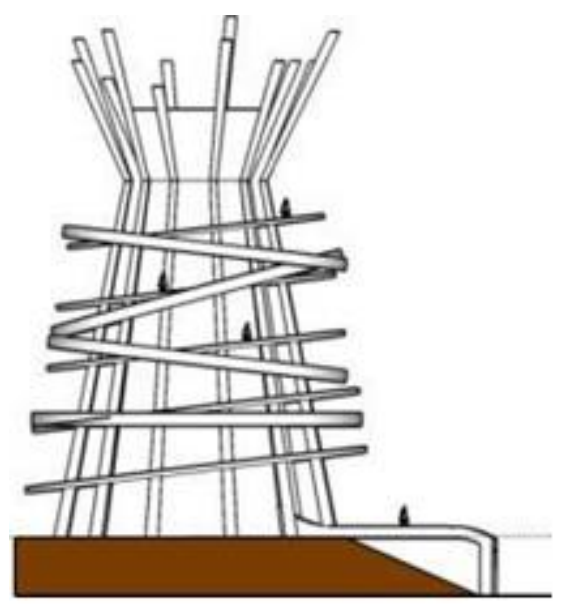

Fig. 9. The Illustration of structure concept.

The use of this steel material provides benefits especially related to the efficiency and timing of construction work because with steel span inter pole can 
reach $60 \mathrm{~m}$ whereas usually if using concrete only $30 \mathrm{~m}$. With such a use the pole will be reduced so it will speed up the work. The $4 \mathrm{~m}$ road width uses a pole size with a diameter of $75 \mathrm{~cm}$ on both sides. The number of poles there are 12 poles with span $6 \mathrm{~m}$. The foundation used is pile foundation. Structure residential use core system with size $15 \mathrm{mx} 15 \mathrm{~m}$.

\section{Conclusion}

Flood is a natural disaster that actually happens because of human behavior itself that does not love the environment around them such as littering and the use of watershed as a settlement. Behavior that seems to have become a culture for humans themselves may be difficult to change but the concept of Tree House is a solution to solve the flood problems that occur in Citarum River Basin by using technology that can accommodate a culture that is difficult to change.

\section{References}

1. A. D. Bolo, H. E. Suhendar, Potret Kebudayaan Masyarakat Penghuni Bantaran Sungai Citarum : Studi Kasus Di Desa Citereup-Kec. Dayeuhkolot, Laporan Penelitian, Lembaga Penelitian dan Pengabdian kepada Masyarakat Universitas Katolik Parahyangan, Bandung (2012)

2. Y. Hidayat, K. Murtilaksono, D. E. Wahjunie, R. D. Panjuju, Pencirian Debit Aliran Sungai Citarum Hulu, Jurnal Ilmu Pertanian Indonesia (JIPI) 18 (2013)

3. Citarum Meluap, Rumah Warga Terendam Lebih dari 1 meter [online]. http://www.pikiranrakyat.com/bandung-raya/2018/03/04/citarummeluap-rumah-warga-terendam-lebih-dari-1-meter420551 [7 April 2018]

4. Y. Hidayat, K. Murtilaksono, D. E. Wahjunie, R. D. Panjuju, The Characteristics of River Discharge of Citarum Hulu, Jurnal Ilmu Pertanian Indonesia (JIPI) 18 (2013)

5. Rencana Pengelolaan Sumber Daya Air Wilayah Sungai Citarum tahun 2016

6. Target Citarum 2018 Gagal [online]. https://www.pressreader.com/indonesia/kompas/201 80105 [7 April 2018]

7. Rencana Pengelolaan Sumber Daya Air Wilayah Sungai Citarum tahun 2016

8. M. F. Ilmansyah, Studi Umum Permasalahan Dan Solusi Das Citarum Serta Analisis Kebijakan Pemerintah, Jurnal Sosioteknologi (2012)

9. Rencana Pengelolaan Sumber Daya Air Wilayah Sungai Citarum tahun 2016 